\title{
Evaluation of the Mood-Stabilizing Agent Valproic Acid as a Preventative for Toxoplasmosis In Mice and Activity Against Tissue Cysts in Mice
}

\author{
Author(s): David G. Goodwin, Jeannine Strobl, Sheila M. Mitchell, Anne M. Zajac, and David S. \\ Lindsay
}

Source: Journal of Parasitology, 94(2):555-557. 2008.

Published By: American Society of Parasitologists

DOI: http://dx.doi.org/10.1645/GE-1331.1

URL: http://www.bioone.org/doi/full/10.1645/GE-1331.1

BioOne (www.bioone.org) is a nonprofit, online aggregation of core research in the biological, ecological, and environmental sciences. BioOne provides a sustainable online platform for over 170 journals and books published by nonprofit societies, associations, museums, institutions, and presses.

Your use of this PDF, the BioOne Web site, and all posted and associated content indicates your acceptance of BioOne's Terms of Use, available at www.bioone.org/page/terms_of_use.

Usage of BioOne content is strictly limited to personal, educational, and non-commercial use. Commercial inquiries or rights and permissions requests should be directed to the individual publisher as copyright holder. 


\title{
Evaluation of the Mood-Stabilizing Agent Valproic Acid as a Preventative for Toxoplasmosis In Mice and Activity Against Tissue Cysts in Mice
}

\author{
David G. Goodwin, Jeannine Strobl*, Sheila M. Mitchell, Anne M. Zajac, and David S. Lindsay†, Department of Biomedical Science and \\ Pathology, Virginia Tech, 1410 Prices Fork Road, Blacksburg, Virginia 24061; *Department of Biomedical Sciences, Edward Via Virginia \\ College of Osteopathic Medicine, Blacksburg, Virginia 24060; †To whom correspondence should be addressed. e-mail: lindsayd@vt.edu
}

\begin{abstract}
Toxoplasma gondii is a common intracellular protozoan infection of humans worldwide. Severe disease can occur in immunocompromised individuals and the in the fetuses of nonimmune pregnant women. Chronic infection is associated with vision and hearing problems, and functional mental alterations, including schizophrenia. The mood-stabilizing agent valproic acid has been shown to inhibit the development of $T$. gondii in vitro at dosages that are normally achieved in the serum and cerebral spinal fluid of human patients and to have positive effects on the behavior of rats chronically infected with $T$. gondii. The present study was done to examine the in vivo activity of valproic acid against acute toxoplasmosis in mice. Two studies were done with valproic acid given in the drinking water at concentrations of $1.5 \mathrm{mg} / \mathrm{ml}$ (Experiment 1) or $3.0 \mathrm{mg} / \mathrm{ml}$ (Experiment 2). In a third experiment (Experiment 3), valproic acid was injected intraperitoneally (i.p.) at doses of 200 or $300 \mathrm{mg} / \mathrm{kg}$ every $12 \mathrm{hr}$. Valproic acid was not effective in preventing acute toxoplasmosis. All mice treated with valproic acid died or were killed and did not $(P>0.05)$ live significantly longer than the controls. Tachyzoites were demonstrated in the tissues of infected valproic-acid-treated mice. A fourth study was done to determine if valproic acid has activity against $T$. gondii tissue cysts in chronically infected mice. Mice were chronically infected with the ME49 strain of $T$. gondii for $8 \mathrm{wk}$ and then treated orally with valproic acid at approximately $6.6 \mathrm{mg} / \mathrm{ml}(800 \mathrm{mg} / \mathrm{kg} /$ day $)$ in the drinking water for $10 \mathrm{wk}$ (amount was varied due to increasing mouse weights). No significant differences $(P>0.05)$ were present in tissue cyst numbers in valproic-acid-treated $T$. gondii chronically infected mice and in mice chronically infected with $T$. gondii but not given valproic acid. Our results indicate that valproic acid, although effective in vitro against $T$. gondii tachyzoites, is not effective as a preventative in mice inoculated with $T$. gondii tachyzoites. Additionally, no activity against tissue cysts was observed in chronically $T$. gondii-infected valproic-acid-treated mice.
\end{abstract}

Toxoplasma gondii is a protozoan parasite that infects humans and most other warm-blooded animals. Humans become infected by ingesting meat containing tissue cysts or by ingesting sporulated oocysts in the environment. Researchers indicate that there are 1,500,000 cases of toxoplasmosis in the United States each year, and about $15 \%$ of those infected have clinical toxoplasmosis (Jones, Kruszon-Moran et al., 2001). The importance of maternal infection and congenital toxoplasmosis has long been recognized (Jones, Lopez et al., 2001). The role of chronic T. gondii infection on human health was manifested in the AIDS epidemic, with the numerous cases of toxoplasmic encephalitis due to reactivated infection and clinical toxoplasmic encephalitis. The association of chronic $T$. gondii infection and behavioral changes has come to light over recent years and has been strengthened by many studies in humans, mice, and rats (Holliman, 1997; Webster, 2001). Most notably, the association of chronic T. gondii infection and schizophrenia has gained attention (Yolken et al., 2001; Ledgerwood et al., 2003; Torrey and Yolken, 2003; Bachmann et al., 2005; Brown et al., 2005; Wang et al., 2006).

Valproic acid is a mood stabilizer used in the treatment of mental illness, including bipolar disorder and schizophrenia (see Bowden, 2007). It has also been shown to inhibit $T$. gondii reproduction in human fibroblast cell cultures (Jones-Brando et al., 2003; Strobl et al., 2007). The $\mathrm{IC}_{50}$ of valproic acid (sodium salt) in a tachyzoite production assay was $266 \mu \mathrm{g} / \mathrm{ml}$ (Strobl et al., 2007), whereas in an ELISA-based assay the $\mathrm{IC}_{50}$ of valproic acid (free acid) was $4.7 \mu \mathrm{g} / \mathrm{ml}$ and the $\mathrm{IC}_{50}$ of valproic acid (sodium salt) was $4.1 \mu \mathrm{g} / \mathrm{ml}$ (Jones-Brando et al., 2003).
These studies indicate that this drug is active against tachyzoites of $T$. gondii.

Rats chronically infected with $T$. gondii lose their innate fear of cat odor (Berdoy et al., 2000; Vyas et al., 2007). This makes them easier prey for cats and enhances the transmission of the parasite. The effects of valproic acid on the feline avoidance behavior of chronically infected rats was examined by Webster et al. (2006) and it was shown to help treated $T$. gondii - infected rats $(40 \mathrm{mg} / \mathrm{kg}$ valproic acid/day orally) retain their innate avoidance of cat smell.

The present study was done to examine the anti- $T$. gondii activity of valproic acid in the prevention of acute toxoplasmosis in mice or activity against the tissue cyst stage in chronically infected mice. Female ICR mice were housed in groups of 5 mice per cage (Experiments 1-3) or 3-4 mice per cage (Experiment 4). Mice in Experiments 1-3 were inoculated subcutaneously with $5 \times 10^{3}$ tachyzoites of the $\mathrm{RH}$ strain of T. gondii on Day 0. Valproic acid was given in the drinking water 1 day prior to subcutaneous inoculation of mice in Experiments 1 and 2. Valproic-acid-containing water in lightproof water bottles was provided ad libitum for the remainder of the study. Fresh valproic-acidcontaining water was provided every 2 days. For dosing considerations, we assumed that each mouse would drink $4 \mathrm{ml}$ of water each day. Saccharin was added at $0.2 \%(w / v)$ to mask the flavor of the valproicacid-treated water.

Experiment 1 contained 10 mice treated with $1.5 \mathrm{mg} / \mathrm{ml}$ valproic acid (Groups 1 and 2) in the drinking water supplemented with $0.2 \%(\mathrm{w} / \mathrm{v})$ saccharin and 10 mice not treated with valproic acid (Groups 3 and 4) (Table I). Saccharin was added at $0.2 \%(\mathrm{w} / \mathrm{v})$ to 1 group of 5 of these mice (Group 3) given water without valproic acid. Experiment 2 contained 5 mice treated with $3 \mathrm{mg} / \mathrm{ml}$ valproic acid in the drinking water (Group 5) and 5 mice not treated with valproic acid (Group 6) (Table II). The mean weight of valproic-acid-treated mice in Experiment 1 was $24 \mathrm{~g}$ and in Experiment 2 the mean weight was $22 \mathrm{~g}$. Valproicacid concentrations in the drinking water provided doses of $250 \mathrm{mg} / \mathrm{kg} /$ day (Experiment 1) and $545 \mathrm{mg} / \mathrm{kg} /$ day (Experiment 2). These dosages translate to $300 \mathrm{mg} / \mathrm{kg}$ and $600 \mathrm{mg} / \mathrm{kg}$ for a $20-\mathrm{g}$ mouse, respectively.

Experiment 3 was done to evaluate valproic acid administered intraperitoneally (i.p.) at doses of 200 or $300 \mathrm{mg} / \mathrm{kg}$ every $12 \mathrm{hr}$ (Table III). The mean weight of valproic-acid-treated mice was $23 \mathrm{~g}$. Valproic acid was dissolved in sterile saline $(0.14 \mathrm{M} \mathrm{NaCl}$ solution $)$ and i.p. injections were started 2 days prior to RH strain $T$. gondii infection with $5 \times 10^{3}$ tachyzoites s.c. There were 2 groups (Group 7 and 8) of 5 mice each that received the 400-mg/kg/day total dose and 2 groups (Group 9 and 10) of 5 mice each that received the $600-\mathrm{mg} / \mathrm{kg} /$ day total dose. A group of 5 mice (Group 11) were infected controls and treated every $12 \mathrm{hr}$ with i.p. sterile saline only.

Experiment 4 (Table IV) was conducted to determine if valproic acid has activity against $T$. gondii tissue cysts in vivo. Eight mice (4 mice in Group 12 and 4 mice in Group 13) were s.c. infected with $1 \times 10^{3}$ tachyzoites of the ME49 strain of T. gondii in $0.5 \mathrm{ml}$ HBSS and left untreated for $8 \mathrm{wk}$. Three mice (Group 14) were s.c. inoculated with $0.5 \mathrm{ml}$ HBSS and treated similarly. After $8 \mathrm{wk}$, mice in Groups 12 and 14 were provided drinking water containing $0.2 \%$ saccharin and approximately $6.6 \mathrm{mg} / \mathrm{ml}$ (amount varied because of mouse weights, which changed during the study) valproic acid for $10 \mathrm{wk}$ to deliver a daily dose of $800 \mathrm{mg} / \mathrm{kg}$. Mice in Groups 12-14 were killed $10 \mathrm{wk}$ after valproic-acid treatment, and their brains were removed. The left half of the brain was homogenized in $2 \mathrm{ml} \mathrm{HBSS}$ for 2 min with the use of a stomacher machine (Seward Lab Blender Stomacher 80, London, England). The numbers of tissue cysts in a 50- $\mu 1$ sample of the homogenized brain was determined with the use of light microscopy. 
TABLE I. Protocol and results of Experiment 1 on $1.5-\mathrm{mg} / \mathrm{ml}$ dose of valproic acid given in the drinking water on acute toxoplasmosis in mice.

\begin{tabular}{|c|c|c|c|}
\hline Group & $\begin{array}{l}\text { Mouse } \\
\text { number }\end{array}$ & $\begin{array}{c}\text { Dose of } \\
\text { valproic acid* }\end{array}$ & $\begin{array}{l}\text { Day post inoculation } \\
\text { died/killed }\end{array}$ \\
\hline 1 & 1 & $1.5 \mathrm{mg} / \mathrm{ml}$ & Died 9 \\
\hline 1 & 2 & $1.5 \mathrm{mg} / \mathrm{ml}$ & Died 10 \\
\hline 1 & 3 & $1.5 \mathrm{mg} / \mathrm{ml}$ & Died 11 \\
\hline 1 & 4 & $1.5 \mathrm{mg} / \mathrm{ml}$ & Died 11 \\
\hline 1 & 5 & $1.5 \mathrm{mg} / \mathrm{ml}$ & Died 12 \\
\hline 2 & 6 & $1.5 \mathrm{mg} / \mathrm{ml}$ & Died 10 \\
\hline 2 & 7 & $1.5 \mathrm{mg} / \mathrm{ml}$ & Died 11 \\
\hline 2 & 8 & $1.5 \mathrm{mg} / \mathrm{ml}$ & Died 12 \\
\hline 2 & 9 & $1.5 \mathrm{mg} / \mathrm{ml}$ & Died 12 \\
\hline 2 & 10 & $1.5 \mathrm{mg} / \mathrm{ml}$ & Died 13 \\
\hline 3 & 11 & None & Died 10 \\
\hline 3 & 12 & None & Died 10 \\
\hline 3 & 13 & None & Died 11 \\
\hline 3 & 14 & None & Died 11 \\
\hline 3 & 15 & None & Died 11 \\
\hline 4 & 16 & None & Died 10 \\
\hline 4 & 17 & None & Died 11 \\
\hline 4 & 18 & None & Died 11 \\
\hline 4 & 19 & None & Died 11 \\
\hline 4 & 20 & None & Died 12 \\
\hline
\end{tabular}

The right half of the brain was fixed in $10 \%$ neutral buffered formalin solution and processed routinely for histological examination following staining with hematoxylin and eosin.

Impression smears were made from the livers or lungs of mice that died or were killed during the study. They were examined unstained for tachyzoites with the use of an Olympus BH60 microscope equipped with interference contrast optics.

Kaplan-Meier survival analysis was performed with the use of PrismGraphpad version 4.0 on mice in Experiments 1-3. The data were analyzed for statistical significance with the use of the chi-square and log-rank tests with a $P$ value of 0.05 . Tissue cyst counts from mice in Experiment 4 were examined with the use of a 1-way ANOVA and an unpaired $t$-test with a $P$ value of 0.05 .

Acute toxoplasmosis occurred in all mice given the RH strain (Tables I-III). Neither oral (Experiments 1 and 2) nor i.p. (Experiment 3) treatment with valproic acid was effective. Deaths occurred in treated mice

TABLE II. Protocol and results of Experiment 2 on $3-\mathrm{mg} / \mathrm{ml}$ dose of valproic acid given in the drinking water on acute toxoplasmosis in mice.

\begin{tabular}{cccc}
\hline Group & $\begin{array}{c}\text { Mouse } \\
\text { number }\end{array}$ & $\begin{array}{c}\text { Dose of } \\
\text { valproic acid* }\end{array}$ & $\begin{array}{c}\text { Day postinoculation } \\
\text { died/killed }\end{array}$ \\
\hline 5 & 21 & $3.0 \mathrm{mg} / \mathrm{ml}$ & Died 11 \\
5 & 22 & $3.0 \mathrm{mg} / \mathrm{ml}$ & Died 11 \\
5 & 23 & $3.0 \mathrm{mg} / \mathrm{ml}$ & Died 12 \\
5 & 24 & $3.0 \mathrm{mg} / \mathrm{ml}$ & Died 12 \\
5 & 25 & $3.0 \mathrm{mg} / \mathrm{ml}$ & Died 12 \\
6 & 26 & None & Killed 10 \\
6 & 27 & None & Killed 10 \\
6 & 28 & None & Died 10 \\
6 & 29 & None & Killed 11 \\
6 & 30 & None & Killed 11 \\
\hline
\end{tabular}

* Provided continuously in water in lightproof drinking bottle to provide an estimated total dose of $545 \mathrm{mg} / \mathrm{kg} /$ day.
TABLE III. Protocol and results of Experiment 3 examining 2 doses of valproic acid given intraperitoneally every $12 \mathrm{hr}$ on acute toxoplasmosis in mice.

\begin{tabular}{|c|c|c|c|}
\hline Group & $\begin{array}{l}\text { Mouse } \\
\text { number }\end{array}$ & $\begin{array}{c}\text { Total dose of } \\
\text { valproic acid* }\end{array}$ & $\begin{array}{l}\text { Day post inoculation } \\
\text { died/killed }\end{array}$ \\
\hline 7 & 31 & $400 \mathrm{mg} / \mathrm{kg}$ & Died 9 \\
\hline 7 & 32 & $400 \mathrm{mg} / \mathrm{kg}$ & Killed 9 \\
\hline 7 & 33 & $400 \mathrm{mg} / \mathrm{kg}$ & Died 10 \\
\hline 7 & 34 & $400 \mathrm{mg} / \mathrm{kg}$ & Killed 10 \\
\hline 7 & 35 & $400 \mathrm{mg} / \mathrm{kg}$ & Killed 10 \\
\hline 8 & 36 & $400 \mathrm{mg} / \mathrm{kg}$ & Died 8 \\
\hline 8 & 37 & $400 \mathrm{mg} / \mathrm{kg}$ & Killed 9 \\
\hline 8 & 38 & $400 \mathrm{mg} / \mathrm{kg}$ & Killed 10 \\
\hline 8 & 39 & $400 \mathrm{mg} / \mathrm{kg}$ & Died 10 \\
\hline 8 & 40 & $400 \mathrm{mg} / \mathrm{kg}$ & Killed 10 \\
\hline 9 & 41 & $600 \mathrm{mg} / \mathrm{kg}$ & Died 9 \\
\hline 9 & 42 & $600 \mathrm{mg} / \mathrm{kg}$ & Killed 10 \\
\hline 9 & 43 & $600 \mathrm{mg} / \mathrm{kg}$ & Died 10 \\
\hline 9 & 44 & $600 \mathrm{mg} / \mathrm{kg}$ & Killed 10 \\
\hline 9 & 45 & $600 \mathrm{mg} / \mathrm{kg}$ & Killed 10 \\
\hline 10 & 46 & $600 \mathrm{mg} / \mathrm{kg}$ & Killed 9 \\
\hline 10 & 47 & $600 \mathrm{mg} / \mathrm{kg}$ & Killed 10 \\
\hline 10 & 48 & $600 \mathrm{mg} / \mathrm{kg}$ & Killed 10 \\
\hline 10 & 49 & $600 \mathrm{mg} / \mathrm{kg}$ & Killed 10 \\
\hline 10 & 50 & $600 \mathrm{mg} / \mathrm{kg}$ & Killed 10 \\
\hline 11 & 51 & None $\dagger$ & Killed 9 \\
\hline 11 & 52 & None & Killed 10 \\
\hline 11 & 53 & None & Died 10 \\
\hline 11 & 54 & None & Died 10 \\
\hline 11 & 55 & None & Killed 11 \\
\hline
\end{tabular}

* Given intraperitoneally as 200 or $300 \mathrm{mg} / \mathrm{kg}$ every $12 \mathrm{hr}$.

$\dagger$ Sterile saline given intraperitoneally every $12 \mathrm{hr}$.

from 8 to 13 days after inoculation with tachyzoites and in untreated mice 9-12 days after tachyzoite inoculation (Tables I-III). There was no significant positive effect of valproic-acid treatment on mouse survival $(P>0.05)$. Tachyzoites were seen in tissues of all mice given the RH strain of $T$. gondii.

None of the mice inoculated with tachyzoites of the ME49 strain of T. gondii died during the study (Groups 12 and 13). None of the mice

TABLE IV. Protocol and results of Experiment 4 on $6.6-\mathrm{mg} / \mathrm{ml}$ dose of valproic acid given in the drinking water* for $10 \mathrm{wk}$ on chronic toxoplasmosis in mice.

\begin{tabular}{|c|c|c|c|c|}
\hline Group & $\begin{array}{l}\text { Mouse } \\
\text { number }\end{array}$ & $\begin{array}{c}\text { Dose of } \\
\text { valproic acid }\end{array}$ & $\begin{array}{l}\text { Inoculated } \\
\text { with } \\
\text { Toxoplasma } \\
\text { gondii }\end{array}$ & $\begin{array}{l}\text { Number of } \\
\text { tissue cysts }\end{array}$ \\
\hline 12 & 56 & $3.0 \mathrm{mg} / \mathrm{ml}$ & Yes & 0 \\
\hline 12 & 57 & $3.0 \mathrm{mg} / \mathrm{ml}$ & Yes & 1 \\
\hline 12 & 58 & $3.0 \mathrm{mg} / \mathrm{ml}$ & Yes & 1 \\
\hline 12 & 59 & $3.0 \mathrm{mg} / \mathrm{ml}$ & Yes & 3 \\
\hline 13 & 60 & None & Yes & 0 \\
\hline 13 & 61 & None & Yes & 1 \\
\hline 13 & 62 & None & Yes & 3 \\
\hline 13 & 63 & None & Yes & 4 \\
\hline 14 & 64 & $3.0 \mathrm{mg} / \mathrm{ml}$ & No & 0 \\
\hline 14 & 65 & $3.0 \mathrm{mg} / \mathrm{ml}$ & No & 0 \\
\hline 14 & 66 & $3.0 \mathrm{mg} / \mathrm{ml}$ & No & 0 \\
\hline
\end{tabular}

* Provided continuously in water in lightproof drinking bottle to provide an estimated total dose of $800 \mathrm{mg} / \mathrm{kg} / \mathrm{day}$. 
given only valproic acid (Group 14) died during the study. Tissue cysts were structurally normal when viewed as fresh preparations with light microscopy. They were also normal when viewed in stained histological sections. The mean number of tissue cysts in $50 \mu l$ was $1.3 \pm 1.3$ (range, 0-3) for mice in Group 12 and $2.0 \pm 1.8$ (range, 0-4) for mice in Group 13. No tissue cysts were seen in the brains of mice in Group 14. There were no significant differences $(P>0.05)$ in tissue cyst counts in mice infected with the ME49 strain of $T$. gondii and treated with valproic acid (Group 12) and those infected but not treated with valproic acid (Group 13).

Valproic acid is active against tachyzoites of $T$. gondii in 2 different cell-culture-based assays (Jones-Brando et al., 2003; Strobl et al., 2007). The studies of Jones-Brando et al. (2003) indicate that valproic acid is active at lower concentrations than reported by Strobl et al. (2007), but both indicate that it is active and the differences are probably due to different test systems used to determine activity.

The results of the present study indicate that valproic acid is not active in preventing acute toxoplasmosis in mice. The highest oral daily dose of $800 \mathrm{mg} / \mathrm{kg} /$ day we tested is approaching the oral $\mathrm{LD}_{50}$ dose of this agent in mice $(1,098 \mathrm{mg} / \mathrm{kg})$; the highest i.p. dose of valproic acid tested, $600 \mathrm{mg} / \mathrm{kg} /$ day, is greater than the $\mathrm{LD}_{50}$ in mice for this route of administration ( $470 \mathrm{mg} / \mathrm{kg}$ ) (American Pharmaceutical Partners, Inc., Bedford Labs, Bedford, Ohio). Therefore, further increasing the dose of valproic acid is impractical. In contrast, Webster et al. (2006) demonstrated that oral treatment of chronically $T$. gondii-infected rats with 40 $\mathrm{mg} / \mathrm{kg} / \mathrm{day}$ of valproic acid was beneficial in their study system. Treated $T$. gondii-infected rats retained their innate avoidance of feline smell (cat urine). The mode of action of valproic acid, including which stage of $T$. gondii is affected by valproic acid in the rats, is not known. Because the rats were chronically infected, it is possible that valproic acid acted on the tissue cyst/bradyzoite stages of $T$. gondii. Valproic acid might also influence the bradyzoite-to-tachyzoite or tachyzoite-tobradyzoite stage conversion. We did not demonstrate a significant $(P>$ 0.05 ) effect of valproic acid on the numbers of tissue cysts in treated mice versus controls. Additional study is needed to examine the activity of valproic acid and similar agents against the tissue cysts/bradyzoites of $T$. gondii.

The study was made possible by funds from a joint research State program between the Carillon Biomedical Institute, Virginia Polytechnic Institute and State University (Virginia Tech), Blacksburg, Virginia, and the University of Virginia, Charlottesville, Virginia, to J.S. and D.S.L.

\section{LITERATURE CITED}

Bachmann, S., J. Schroder, C. Bottmer, E. F. Torrey, and R. H. YOLKEN. 2005. Psychopathology in first-episode schizophrenia and antibodies to Toxoplasma gondii. Psychopathology 38: 87-90.

Berdoy, M., J. P. Webster, And D. W. Macdonald. 2000. Fatal attraction in rats infected with Toxoplasma gondii. Proceedings of the Royal Society B 267: 1591-1594.
BowDEN, C. L. 2007. Spectrum of effectiveness of valproate in neuropsychiatry. Expert Reviews in Neurotherapy 7: 9-16.

Brown, A. S., C. A. Schaefer, C. P. Quesenberry, Jr., L. Liu, V. P. Babulas, AND E. S. Susser. 2005. Maternal exposure to toxoplasmosis and risk of schizophrenia in adult offspring. American Journal of Psychiatry 162: 767-773.

Holliman, R. E. 1997. Toxoplasmosis, behaviour and personality. Journal of Infection 35: 105-110.

Jones, J. L., A. Lopez, M. Wilson, J. Schulkin, And R. GibBs. 2001. Congenital toxoplasmosis: A review. Obstetrical and Gynecological Survey 56: 296-305.

, D. Kruszon-Moran, M. Wilson, G. McQuillan, T. Navin, AND J. B. MCAUley. 2001. Toxoplasma gondii infection in the United States: Seroprevalence and risk factors. American Journal of Epidemiology 154: 357-365.

Jones-Brando, L., E. F. TORREy, And R. H. Yolken. 2003. Drugs used in the treatment of schizophrenia and bipolar disorder inhibit the replication of Toxoplasma gondii. Schizophrenia Research 62: 237 244.

Ledgerwood, L. G., P. W. Ewald, and G. M. Cochran. 2003. Genes, germs, and schizophrenia: An evolutionary perspective. Perspectives in Biological Medicine 46: 317-348.

Strobl, J. S., M. Cassell, S. M. Mitchell, C. M. Reilly, and D. S. LINDSAY. 2007. Scriptaid and suberoylanilide hydroxamic acid are histone deacetylase inhibitors with potent anti-Toxoplasma activity in vitro. Journal of Parasitology 93: 694-700

TORREY, E. F., AND R. H. YolKen. 2003. Toxoplasma gondii and schizophrenia. Emerging Infectious Diseases 9: 1375-1380.

Vyas, A., S. K. Kim, N. Giacomini, J. C. Boothroyd, And R. M. SAPOLSKY. 2007. Behavioral changes induced by Toxoplasma infection of rodents are highly specific to aversion of cat odors. Proceedings of the National Academy of Sciences of the United States of America 104: 6442-6447.

Wang, H. L., G. H. Wang, Q. Y. Li, C. Shu, M. S. Jiang, and Y. Guo. 2006. Prevalence of Toxoplasma infection in first-episode schizophrenia and comparison between Toxoplasma-seropositive and Toxoplasma-seronegative schizophrenia. Acta Psychiatrica Scandinavica 114: 40-48.

Webster, J. P. 2001. Rats, cats, people and parasites: The impact of latent toxoplasmosis on behaviour. Microbes and Infection. 3 : 1037-1045.

- , P. H. Lamberton, C. A. Donnelly, And E. F. Torrey. 2006 Parasites as causative agents of human affective disorders? The impact of anti-psychotic, mood-stabilizer and anti-parasite medication on Toxoplasma gondii's ability to alter host behaviour. Proceedings of the Biological Society B 273: 1023-1030.

Yolken, R. H., S. Bachmann, I. Ruslanova, E. Lillehoj, G. Ford, E. F. Torrey, And J. Schroeder. 2001. Antibodies to Toxoplasma gondii in individuals with first-episode schizophrenia. Clinical Infectious Diseases 32: 842-844.

\section{Molecular Characterization of Babesia kiwiensis From the Brown Kiwi (Apteryx mantelli)}

R. Jefferies, J. Down, L. McInnes, U. Ryan, H. Robertson`, R. Jakob-Hoff $\dagger$, and P. Irwinł, School of Veterinary and Biomedical Sciences, Murdoch University, Murdoch, 6150, Western Australia, Australia; *Research, Development and Improvement Division, Department of Conservation, P.O. Box 10-420, Wellington, New Zealand; †New Zealand Centre for Conservation Medicine, Auckland Zoo, Grey Lynn, Auckland, New Zealand; 抽 whom correspondence should be addressed.e-mail: P.Irwin@murdoch.edu.au

ABSTRACT: To further investigate the recently described avian piroplasm, Babesia kiwiensis, blood samples were collected from 13 wild-caught and 8 zoo-captive brown kiwi (Apteryx mantelli) and screened for the presence of piroplasm DNA using a nested-polymerase chain reaction (PCR) targeting the 18S rRNA gene of most members of Piroplasmida. All captive birds gave a negative PCR result, while 12 wild-caught birds were PCR positive. The nearly full-length $18 \mathrm{~S}$ rRNA gene for B. kiwiensis was sequenced. Upon phylogenetic analysis, it was found to belong to the babesid group of piroplasms and was ancestral, yet genetically similar, to the $B a$ besia canis-related species. An insight into the current taxonomy of the avian piroplasms is also given. An Ixodes anatis tick collected from 1 of the North Island brown kiwi was also screened using PCR and was found to be positive for B. kiwiensis DNA.

The avian piroplasms (Piroplasmida) remain an understudied group of protozoans. In comparison to many of the mammalian species of 